\title{
Examining Deterrence and Backlash effects in counterterrorism: the case of ETA
}

\begin{abstract}
Scholars are increasingly drawing on models and theories from the field of criminology to offer new insights on terrorist violence. A particularly useful framework by LaFree, Dugan and Korte works from the assumption that illegal behaviour can be affected by the threat and/or imposition of punishment. It sees the results of the government's intervention in terms of deterrence (state's repressive action leads to a reduction in terrorism violence) and backlash (state's repressive action leads to defiance and retaliation and an upsurge of terrorism violence). This article applies this model to a case study of the government's responses to Euzkadi Ta Askatasuna (ETA). It uses a variation of survival analysis technique -Series Hazard- to assess the impact of six major initiatives on the risk of new ETA attacks in the period from 1977 to 2010. Mostly, the results provide support for both backlash interpretations although important questions regarding interpretation are raised.
\end{abstract}




\section{Introduction}

The study of terrorism, traditionally dominated by approaches from political science and psychology, is becoming increasingly informed by insights emerging from the field of criminology. After a slow start, theories and methods that have been employed for years in the study of 'normal' crime are now being applied to terrorism data. These criminological approaches offer new insights on a variety of aspects, including the funding tools for clandestine activity, the relationship between organised crime and political violence, targethardening strategies against terrorist attacks or the evaluation of the effectiveness of counterterror strategies.

Precisely in relation to the latter dimension, a 2009 article by LaFree, Dugan and Korte made a number of important methodological and theoretical contributions. ${ }^{1}$ The study examined the impact of six specific British counterterror strategies on Republican violence over a 23-year period, using an extension of the Cox Hazard model to determine the effect of these measures on the duration between attacks. LaFree et al. had already utilised this statistical approach in a 2005 paper on airline hijackings, ${ }^{2}$ but this more recent study highlighted the effective application of two concepts with a long pedigree in criminology: deterrence and backlash.

The principle that the threat and imposition of punishment deters crime is, of course, at the centre of criminal law. The fundamental assumptionhere is that individuals are rational actors that would try to maximise their personal gain while minimising costs and would alter their behaviour based on cost-benefit calculations. Therefore a higher chance of apprehension or a harsher punishment from the state would therefore discourage more people from breaking the law.

This perspective has dominated western counter-terror responses, as illustrated by the frequency in which the emergence of sub-national violence is immediately confronted with new laws with harsher penalties for serious crimes and longer prison sentences when they are committed by members of terrorist organisations. The traditional response not only relies on raising the threshold of punishment but also to make the threat of punishment more credible by giving new powers and more resources to law enforcement and intelligence agencies. Decision makers and legislators expect these measures to prevent and deter future acts of violence.

At the same time, criminological research has also demonstrated that repressive measures may in fact fail ${ }^{3}$ and,in some cases, even have the opposite effect, say, an increase of the illicit behaviour or a 'backlash'. This finding is particularly relevant for the study of terrorism, where it has been suggested that greater state repression can exacerbate political violence because of the grievances it generates.A theme that regularly emerges in the terrorism studies literature on why terrorism declines or ends ${ }^{4}$ is that hard-line policies do not always succeed and can even backfire.

The rationale is that increased government repression may motivate violent actors to retaliate. Further, when a coercive government response is widely believed to be illegitimate and/or disproportionateby the community from which the group originates, then this may elicit acts 
of defiance and additional outpouring of support for the group. In practice this may get translated into successful recruitment drives and/or an increased likelihood that supporters and sympathisers will financially sponsor or operationally assist the organisation. At the same time, draconian internal security measures run the risk of undermining support for the government's counterterrorist efforts amongst the wider population. In sum, by provoking the authorities to resort to excessive repression, these militant groups can portray themselves as protectors of the population and, in the process, erode popular support for the government.

These two notions of deterrence and backlash are clearly operationalised byLaFreeet al. The authorsconsider that 'a significant decrease in the hazard of new strikes after a major government counterterrorist intervention is consistent with a deterrence effect, and that a significant increase is consistent with a backlash effect. A null effect suggests that either no relationship exists or that deterrence and backlash dynamics have neutralized each other'. ${ }^{5}$

LaFree et al. concludedtheir article by advocating for the application of this deterrencebacklash framework to other existing political conflicts. Thus, this study answers this call by examining a list of counterterror interventions ${ }^{6}$ adopted in the fight against Euzkadi Ta Askatasuna (ETA), the Basque separatist organisation. It applies the conceptual and methodological approach developed by LaFreeet al. to the ETA case study to test the generalisability of their conclusions and contribute to a process of theory development.

For us, ETA is a natural comparison case for the LaFree et al. Irish Republican Army-based analysis. Although oft-overlooked fundamental differences exist between the political conflicts in Northern Ireland and the Basque Country, ETA and the IRA do share similarities: First, they are both ethno-nationalist groups that grew in the 1970s wave of radical nationalist violence. Second, both have had long histories of armed struggle: The Provisional IRA was active from 1969 until 1998 whereas ETA was founded in 1959 and, at the time of writing, still exists. These parallels allow us to explore whether LaFreeet al.'sfindings remain relevant when examining government responses to other militant groups that pursue similar nationalist political goals through protracted campaigns of violence.

We have identified in our analysis six counter-terrorist interventions used by both the Spanish and the French governments to confront ETA violence in the period 1977 to 2011. The goal was not necessarily to test interventions that could be hypothesised in advance to have effectively combated ETA but to measure the impact of high-profile initiatives for which substantial coverage existed in the media and academic literature and whose modelling could lead to rich insights on the interplay between deterrence and backlash effects.

Using data from the Global Terrorism Database (GTD) and the Spanish Ministry of the Interior, we ended up with a dataset containing 1,713 incidents for the period. We then applied Series Hazardmethods (an extension of Cox proportional hazard model) to the data to determine whether the risk of attacks was significantly affected after the interventions were implemented. In the model we controlled for the impact of political factors and other statistical effects. A significant decrease in the hazard of future incidents of violence is seen 
as evidence of a deterrence effect, while anincrease in the hazard of future incidents of violence is interpreted as evidence of a backlash effect.

Before presenting our findings, we provide first an overview of relevant literature. We then summarise the evolution of this militant group and describe those state responses that have been considered in the study. We then proceed to review the model and variables and present the results. We discuss them in the last section, explain their relevance and suggest further avenues of research.

\section{Literature Review}

For the sake of brevity, we focus on examining those works that specifically look at Spanish counter-terror strategies against ETA terrorism, where one soon realises that the majority of studies are qualitative.Only a handful of evaluations of the effectiveness of counter-terror policies against ETA rely on formal statistical tests. Nevin, for instance, uses Spanish policies against ETA from 1973 to 1983 as one out of seven case studies of government counterterror strategies. Nevin's article focuseson whether retaliation reduces or increases terrorism and, in answering it through lagged time series models, findsthat, for the particular case of ETA, government retaliation led to increased terrorist action, a finding that contradicts deterrence models. ${ }^{7}$ However, Nevin does not distinguish or test separately for the effects of specific counterterror tactics when he discusses retaliation, a broad concept that incorporates without distinction a wide variety of potential government responses, from arrests through targeted killings to large-scale military attacks.

A 2003 article by Barros aims at evaluating the influence of a series of factors on ETA violence using as method a vector autoregression time series framework. ${ }^{8}$ As in Nevin's study, the model does not include individual counterterror interventions as variables.Barros finds that deterrence effects and economic variables do not exert any significantinfluence while political effects seem to provoke more terrorist incidents. Based on this, it is predicted that the banning of Batasuna, an intervention that is also assessed in this article, would likely lead to more terrorism. The study relies on annual data and, as we later discuss, Dugan and others have highlighted the important advantages that survival analyses have over time series models when applied to disaggregated incident data in assessing the impact of counterterror policies. $^{9}$

Hence, Barros, in collaboration with Passos and Gil-Alana, used duration models as an alternative in a 2006 paper. They employ a series of parametric and semi-parametric hazard models to examine the impact of a number of factors on the length of time between ETA terrorist attacks. Their conclusion is that 'ETA attacks increase in summer and decrease with deterrence, repressive political governments, succedaneum terrorist activities, murders and political accords ${ }^{10}$ An issue with this study is their use of ITERATE data since, as discussed in the methodology section, this source contains only transnational attacks whereas ETA terrorism is overwhelmingly domestic. ${ }^{11}$ 
There are two studies that come closer to the analytical framework adopted here. Gil-Alana and Barros look at proactive and reactive deterrence policies in fighting ETA terrorism in a 2010 article and, in a conference paper of the same year ${ }^{12}$, Chenoweth and Perkoski apply a Cox Hazard model to ETA data. ${ }^{13}$ The latter do so for the period 1988-1992 to argue that discriminate restrictive policies (i.e. arrests) are the most robust reducers of terrorist activity out of the menu of options available to the government.Differences between Chenoweth and Perkoski's paperand this study include the length of the period under investigation (we extend the period further than 5 years), the fact we are selecting specific strategic interventions instead of their choice of categories of tactical action (i.e. Condemnations, arrests, deportations and others) and our adoption of a deterrence/backlash conceptual model to interpret the results.

On the other hand, Gil-Alana and Barros' paper assesses the effectiveness in the fight against ETA of Spanish proactive and defensive deterrence policies, which are broken down further into political and retaliatory initiatives. The article's main argument is that political proactive measures are effective in reducing ETA activity whereas,in most cases, proactive retaliatory policies are not. We have included as variables in our model some of the initiatives they test but also introduce others based on their visibility and importance within the existing literature on Spanish counter-terrorism. ${ }^{14}$ Apart from divergences in the selections of variables, unit of analysis (killings instead of incidents) and data sources, Gil-Alana and Barros did use a different statistical method (Poisson count models) from the one implemented here.

In sum, evidence for the impact of Spanish antiterrorist strategies is varied, with some studies showing support for deterrence measures and others presenting mixed evidence or no significant effects.

\section{The ETA Case Study}

Before we describe our own approach, we provide a concise overview of the case study. In the process we will highlight the specific developments that we include as primary and control variables in the model.They appear in bold and will be later described in detail in the methodology section(see also Table 1 and 2 for the full list of variables in the model).

ETA (Euzkadi Ta Askatasuna- Basque Homeland and Freedom) is the largest remaining ethno-nationalist terrorist organisation in Europe. Founded in 1959 during the Franco dictatorship as a splinter group of the youth group of the historic PNV (PartidoNacionalista Vasco - Basque Nationalist Party), its main political goal is the independence of the Basque Country. ${ }^{15}$

ETA's first attack took place in 1961 with an attempt toderail a train carrying civil war veterans travelling to San Sebastián. The organisation did not claim its first victim until 1968 and during most of Franco's dictatorship only engaged in sporadic acts of violence.In fact, it was notuntil the mid-1970s when ETA began carrying out large scale terrorist 
activity. ${ }^{16}$ During the transition from authoritarian rule there was a dramatic upsurge in their violenceand the 1978-1980 period was the bloodiest in ETA's history.

Throughout 1977 and early 1978 the strategy of the first democratic government to tackle the high levels of political violence in the country ${ }^{17}$ was to progressively liberalise the regime, as represented by the granting in October 1977 of a general amnesty to all political prisoners. However, the hopes by the Spanish political elites that ETA's political violence would recede with progress towards democracy were soon dashed: the number of terrorist incidents continued growing fast and so did the pressure for a more repressive response to ETA's actions.

The turning point towards a harsher Spanish Antiterrorist policy -and the first intervention examined in this study- is the 1 July entry into force of Law 21/1978, which gave the police new powers of arrest and detention. As Clark describes: 'Suspects could be held without charges filed against them for more than seventy-two hours [..] Police were also granted the right to intercept mail and telephone messages received by suspected terrorists. [..] Amnesty and pardons for terrorist crimes were also ruled out and courts were not allowed to release prisoners on bond before trial'. ${ }^{18}$ The Law remained Spain's basic antiterrorist law for about eighteen months. ${ }^{19}$ Importantly, Alonso and Reinares have described how these provisions were intended to support police's work but, because they were enforced by security agencies that were still unreformed and lacking the ethos and professional culture appropriate for a democratic society, the legislation resulted in cases of mistreatment and torture. ${ }^{20}$

In parallel with a more coercive security approach, in 1979 the approval by referendum of the Estatuto de Autonomíadel País Vasco (Basque Autonomy Statute) -also known as the Guernica Statute- led during the 1980s to the Basque Autonomous Community (BAC) gradually achieving significant levels of self-government. These included a Basque Parliament and regional government, its own police force (the Ertzaintza), independent fiscal, educational and health systems and a public television and radio stations (EuskalIrratiTelebista-EITB) broadcasting in the Basque language (Euskera). Despite these evident signs of progress, ETA violence persisted unabated during the whole period.

The 1982 Socialist government deepened the trend towards more coercive and stringent counter-terror policies. By far the most controversial element of this response is the establishment of a clandestine paramilitary group to assassinate ETA members and sympathisers in Southern France. The GruposAntiterroristas de Liberación(Antiterrorist Liberation Groups), better known by their acronym GAL, were a state sponsored group consisting of members of the state security forces, right-wing extremists and foreign mercenaries who killed 27 people -many of whom turned out to have no relationship whatsoever with ETA- during the 1983-1987 period. ${ }^{21}$ The two main reasons behind the establishment of this group were: a) to operatein the French Basque Country, which had acted as a safe haven for ETA members over the years, a place to train, recruit, plan operations, indoctrinate and to escape from the Spanish forces' pressure; and b) to put pressure on the French government to end ETA's use of their territory. 
Obviously, this example of state terrorism was a secret operation and never a formal government policy but responsibility for its planning, organisation and funding came from the highest echelon of the state's security decision-makers: amongst others, the then Secretary of State for Security and Minister of the Interior were eventually charged, prosecuted and imprisoned for setting up the group. This aspect of the dirty war, a notorious chapter in the Spanish state's fight against ETA, is therefore considered as a state intervention in the context of this study.

Persistent lobbying by the Spanish government and French concerns over the spill-over of the Basque violence into their own territory eventually led to a change of policy. Frenchpolicies vis-à-vis ETA significantly toughened, firstly by deporting their members to other countries and, eventually and, starting from 1984, by extraditing them directly to Spain. The short and long-term effects from the introduction of these measures are also measured in the model.

Since the mid-1980s, there has been an ever increasing degree of cooperation between these two countries. In fact, experts and practitioners have traditionally considered French support as fundamental in combating ETA violence. Hence, the first major police operation resulting from enhanced French-Spanish cooperation constitutes the fourth intervention in the model. On November 5, 1986, acting from information passed by the Spanish ministry of interior, a raid by the French security forces at the Sokoa furniture plant in Hendaye, a town in the French Basque Country, led to the retrieval of a large arsenal of ETA weapons and explosives and the arrest of 11 members and collaborators. In addition, a massive cache of documents containing information on the organisation's finances were seized.

A year later, in January 1988, all the major Basque political forces, with the exception of ETA's political armHerriBatasuna (Unity of The People), signed the agreement known as the Pact of Ajuria-Enea. Signatories agreed on the necessity of the eradication of terrorism from Basque Country and the illegitimacy of violence as tool to achieve political change. Meanwhile, a root-and-branch reform of the security services continued purging surviving Francoist elements, leading to more targeted, consistent and discriminate counter-terror practices that were more respectful of the individual rights. The overall number of arrests diminished but the proportion of those who resulted in prosecutions increased and cases of police brutality and ill-treatment were greatly reduced. Their use as a systematic practice became progressively eradicated during the 1990s. ${ }^{22}$

Although the first official negotiations -and accompanying ceasefire- between representatives of ETA and the Spanish government conducted in 1989 in Algiers ended in failure, French-Spanish collaborationgrew closer and continued yielding results. A key security breakthrough was the fall of the entire ETA leadership in a police operation in Bidart (Southern France) in March 1992. Using intelligence provided by the Guardia Civil, the French police arrested in a single swoop ETA's complete executive committee. ${ }^{23}$ This intervention, the fifth in our model, is seen as having forced ETA to reconfigure their management structures, rebuild parts of the organisation, and strengthen the security measures of their militants. 
It also led to a process of internal reflection and an eventual strategic shift in 1995. Then, as Sánchez-Cuenca details: 'a new emphasis was added on the necessity of achieving independence not in direct negotiations with the state, but rather through an agreement with all nationalist forces in the [BAC], ${ }^{24}$

This entailed two aspects. Firstly, a change in the target selection, as non-nationalist politicians, academics, journalists, intellectuals and other groups in society became priority targets. ${ }^{25}$ The goal was to 'Ulsterise' the region, that is, to create two divided communities within Basque society (nationalists and non-nationalists) where moderate nationalists would be forced to join ETA's side.

To further this strategy of extending violent action into wider sectors of Basque society, Jarrai, the youth wing of the Movimiento de LiberaciónNacional Vasco(MLNV), the dense network of institutions that surrounded ETA, became engaged in the so-called Kale Borroka(street fighting) campaign. These were acts of street hooliganism, described as 'low intensity terrorism' that often took the form of harassment and death threats to non-nationalist public figures and/or local councillors. ${ }^{26}$ As a result of these, and coupled with ETA's killings, hundreds of individuals were forced to leave Basque Country or be assigned bodyguards for their protection.

The second element in the strategy was to form a nationalist political front. Under the promise of an eventual end to the armed struggle, ETA political representatives signed on September 12, 1998, together with all other major nationalist parties, the so-called Lizarra Pact. In exchange for ETA renouncing violence, these political parties agreed to fight for the independence of Basque Country, to renege from the AjuriaEnea Pact and to isolate nonnationalist parties. Following the signature, ETA announced a truce in September 16, 1998 that it broke again only a few months later on November 28, 1999. Seemingly, the organisation was disappointed with the 'slow' pace of the political process and the lack of results from the contacts maintained in places like Zurichwith the Spanish government during this period. ETA's decision resulted in moderate nationalist parties breaking their links with the group and the eventual end of the Lizarra strategy.

As a reaction, PSOE and PP, the two main Spanish political parties, signed on 8 December 2000 an agreement,Acuerdoporlaslibertades y contra el terrorismo, that prevented the achievement of any political goal through terrorist violence. Most importantly, this accord brought about the political conditions that led to the passing in 2002 of the Ley de Partidos, a legislation that made political parties connected to a terrorist organization illegal. This is the mechanism that facilitated the very same year the banning of Batasuna, ETA's electoral wing. This measure represents the last intervention included in the analysis.

As a result of the failure of the 1995 strategic shift, ETAfound itself without direction and on March 22, 2006 announced a 'permanent ceasefire'. The Socialist government agreed to initiate talks with independent mediators in Geneva and Oslothat failed to come to fruition. ETA abruptly breaks the impasse on December 30, 2006 with the explosion of a car bomb in Barajas airport in Madrid, which killed two people. After a series of murders, on January 10, 
2011, ETA, devoid of broad popular support and suffering from a dramatically reduced capacity for action, declares a 'permanent and internationally-verifiable ceasefire'. At the time of writing, the truce continues being uphold.

\section{Methodology}

\section{Data}

Similar to LaFree et al., our study is based on incident data collected from the Global Terrorism Database (GTD). ${ }^{27}$ The GTD is the most comprehensive source of data on terrorism across the globe and its clear coding techniques and overall reliability makes it one of the most utilised resources by scholars in the field. ${ }^{28}$ What separates GTD from other similar databases such as RAND-MIPT and ITERATE is that it includes both domestic and international terrorist incidents. This is particularly important for the ETA case study since the vast majority of their violent actions have been conducted either in Basque Country or other parts of Spain. ${ }^{29}$

After a comprehensive cleaning of the data and complementing the GTD file with open source information from the Spanish Ministry of the Interior ${ }^{30}$ and evidence from Vidas Rotas, a compendium of victims assassinated by $\mathrm{ETA}^{31}$, ourfinal analysis file contained a total number of 1,713 ETA incidents. The dataset includes all recorded ETA attacks both inside and outside Spain. The geographical distribution of the incidents occurred within the country and the French departments that border Spain can be examined in a map at Appendix B.

We consider the period from January 1, 1977, through January 10, 2011, as the span of time for our analysis. ${ }^{32}$ The end date coincides with ETA's declaration of a 'definitive cessation' of armed activity. This occurs 8 years after the most recent initiative in this analysis is introduced-the banning of Batasuna, ETA's political arm-. It is important to note that all interventions in the study have been conducted under democratically-elected governments.

\section{Methods}

As described in the introductory section, we follow the strategy set by LaFreeet al. in their use of a variation of Cox proportional hazard models to estimate the impact of the selected six counterterror interventions on the risk of future ETA attacks. Since the publication of this article, Dugan has convincingly demonstrated that Cox-type models work well for event data and referred to this variation as a Series Hazard Model. It offers a better alternative to time series when estimating the impact of multiple interventions mostly because it does not require the temporal aggregationof data and it is therefore more effective in capturing variation in the dependent variable while controlling for the effects of independent variables. ${ }^{33}$ 
The outcome variable in a Series Hazard model is the time between attacks, and the units are terrorist attacks instead of subjects. Interventions enter in the model as dummy variables and the model can be adjusted by other control variables measured at the time of eachattack. Similarto LaFreeet al., when more than one incident in the dataset are part of a coordinated act of violence, then cases have been converted to represent these multiple-part events as a single attack. The mean number of days between attacks was 7.18 days. The distribution is asymmetric with 3 and 7 days constituting the $50^{\text {th }}$ and $75^{\text {th }}$ percentile respectively.

In practical terms, this means that the equation used for the analysis is:

$$
\lambda_{k}\left(t \mid X_{k}\right)=\lambda_{0} \exp \left(\beta_{i} \text { Government Interventions }_{i k}+\gamma_{j} \text { Controls }_{j k}\right)
$$

Where $k$ represents each terrorist attack, $\beta_{i}$ represents the coefficients for the interventions and $\gamma_{j}$ are the coefficients for the variables used as controls. To measure the impact of the interventions, we used a series of dummyvariables with values of " 1 " for attacks that were perpetrated during theperiod relevant to the intervention and " 0 " otherwise. The hazard of a new attack is associated to baseline hazard function with unspecified distribution and other risk or protective factors measured at the time of the current attack represented by the vectors 'Government Interventions' for the punitive initiatives against ETA and 'Controls' for the control variables.

The variables used in the analysis are listed in the following table. ${ }^{34}$

\section{HERE TABLE 1}

\section{Government Interventions}

The present study includes six state interventions. Fourof these interventions occurred during the 1980s, a period when Spanish counter-terror policies are in flux, witha wide range of different initiatives being performed. Some will become permanent elements of the counterterror response, others will have fleeting existence.It is by the end of the 1980s when the state's counter-terror apparatus consolidates.

Thus, our first criminal justice intervention is the introduction of the Law/21 1978, which took effect on July 1, 1978. It was phased out when the Spanish Congress of Deputies approved on October 29, 1980 the Organic Law on Citizen Security, which codified and replaced the provisions of the preceding anti-terrorist laws. Therefore the legal intervention was coded as "1" from July 1, 1978 to October 29, 1980.

The other major example in the model of Spanish legislative action, the banning of Batasuna, has a less precise starting date. It is on June 4, 2002 when the Organic Law 6/2002 (Ley de PartidosPolíticos) is passed by the Spanish Parliament and 27 June when it comes into force. This legislation would allow the PP and PSOE to start on August 13 the process resulting in the illegalisation of Batasuna, ETA's political arm, carried out by requesting the state's Prosecution Office to initiate legal action. However, we have adopted August 26 as the 
starting date for the intervention period because this is precisely when the Spanish judge BaltasarGarzóninitiates the legal proceedings to suspend Batasuna's political activities. ${ }^{35}$

The most controversial of this list of state interventions were the activities of GAL, whose period of action runs from the date of their first murders in October 17, $1983^{36}$ toJuly, 24 1987. ${ }^{37}$ The two police operations included in the model, Sokoa and Bidart, have clear starting dates: the French police raid at Sokoa was conducted on November 5, 1986 and the arrest of ETA leaders in Bidart on March 29, 1992. Formally, they lasted one day. However both operations, products of French-Spanish counter-terror cooperation, resulted in important arrests and the collection of internal documents that represented a treasure trove of intelligence. Hence, they are considered as having eventually brought about further arrests and disruption of ETA's operations. Therefore, it is difficult to precise a specific end date.

Following LaFree et al.'s strategy, when these circumstances arise, weinitially set the end time for the events at 1 year. In the Bidart case, the period intervention finalised before the start of the next initiative, so there was no overlap. However, as we will see later, this was not always the case.

At the same time, in case the 1-year cut-off proved too limiting, we explored other time windows for interventions and controls with a non-defined end. Thus, we programmed a set of models where the control variables were forced into the model and the interventions selected with a backward selection method, varying the period for those interventions without a clear end date. We then compared the models using the Akaike Information Criterion (AIC). A combination of the simulation analysis ${ }^{38}$ and the visual study of Figures 1 and 2 suggested the use of one and three yearsperiods to assess the impact of those interventions. Once the final model was established, we also conducted sensitivity tests that vary the end dates with monthly increases to measure the impact in the estimates. Furthermore, to test for the possibility that hazard changed within the intervention period, we included an interaction term between each intervention and the cumulative month since the beginning of the study period.

The third criminal justice procedure, the start of systematic deportations and extraditions of ETA members living in Southern France was of course conducted by the French government. These, however, would not have occurred without Spanish government's insistence and lobbying efforts. Thus, although French-Spanish cooperation is formalised at the June 14, 1984 Acuerdos de la Castellana, Spanish pressure had already begun to pay dividends by early 1984, where the major change in French policy was signalled by the immediate deportation of six arrested members of ETA, first to Guadeloupe and then to Panama. ${ }^{39}$

Here we face the same issues than with the two police interventions above: an indeterminate concluding date, since French extradition of alleged Etarras continues until this day. Hence, we have measured its effects in three ways: the short-term impact, one that ends in one year, another medium-term impact in three years and ,finally, long-term: until the end date of the study. 


\section{Control Variables}

To control for the presence of alternative explanations, we have produced a list of relevant variables.

First, negotiations: This variable refers to those formal negotiation processes established between the Spanish Government and ETA leaders as a result of, during, or leading to an ETA truce. Although the Spanish government and ETA have established channels of communication several times over the past four decades, including half a dozen attempts to negotiate a ceasefire between 1977 and $1980^{40}$, the three periods that are included in the variable did lead to sustained and formalised talks. These encompass three separate processes: the negotiations between ETA and the Gonzalez Socialist government during 14 January-7 April 1989 in Algiers ('Algiers'), the set of contacts between PartidoPopular's Aznar government and ETA between November 3, 1998 and November 28, 1999 that included a formal meeting in Zurich ('Zurich') and the talks carried out under former Socialist leader's Zapatero in Geneva and Oslo from June 25, 2005 to May 21, 2007 ('Oslo').

Due to the reason explained above, the periods included in the control variable ceasefires tend to overlap with the negotiations variable. Although ETA has unilaterally interrupted their attacks for very brief periodsin a few occasions, we are including in the model the longest and most politically significant ETA ceasefires: 8 January - 4 April 1989, 16 September - 28 November 1999 and 22 March 2006 - 30 December 2006. Due to the existing overlaps, we therefore decided to merge the negotiations and ceasefires periods in our model, using the earliest and latest dates to set the time boundaries of the three control variables ('Algiers', 'Zurich', 'Oslo').

In addition, we have two political controls: Guernica Statute and Ajuria-Enea Pact. To allow sufficient time for the first results from the Statute to take place we resorted to a three year period and the effects of Ajuria-Enea are assumed to lasts until the signing of the 1998 Lizarra Pact, which dissolves temporarily the political consensus on counterterrorism amongst Basque nationalist and non-nationalist parties thatAjuria-Enea built.

We also included statistical controls suggested in LaFree et al. paper to explain the expected correlation between incidents:

To control for the momentum of previous attacks, a measure of attack densityhas been added. This represents the number of days covered by the three most recent attacks, which includes the current attack. We also explored the option of including the seven most recent attacks, as suggested by Dugan ${ }^{41}$, and autoregressive terms but the variability explained by the density variable based on three attacks was clearly larger than any other variable's, and this was also supported by the AIC values measure when comparing models. ${ }^{42}$

Additionally, Cumulative month is suggested in Dugan's paper to adjust for trends. The median (Interquartile range) number of attacks occurred 113 (130) months into the series. We included interactions between this variable and each state intervention to assess whether the hazard ratio varies across the intervention. 
To conclude our overview of the model, Figures 1 and 2 present the monthly number of attacks with all the interventions and controls imposed.

\section{HERE FIGURES 1 AND 2}

For the sake of clarity, we divide the research period into two separate phases tobetter display the evolution of ETA's violence and the timing of the interventions. Most of our variables can be found in the first period and, almost inevitably due to their closeness in time, overlaps exist. This is especially the case for the GAL and French extraditions variables, where the former's intervention period contains the latter's in its entirety. As we will later explain, this entailed importantmodelling and methodological challenges.

\section{Hazard Model Results}

At first sight, the initial conclusion that can be adopted from the results of the analysis is the importance of statistical controls for this type of models. It should be noted that the variable attack density explains much of the variability in the model. Hence, the risk of new attacks seems to be substantially related to the periodicity of the previous three attacks. In other words, when the three most recent attacks occurred over a short period of time, the risk of another ETA attack taking place is high. The methodological implications are obvious as these results support LaFree et al's decision to include this variable as a mechanism to reduce the bias caused by possible endogeneity between earlier attacks and the timing of interventions. It also demonstrates the importance of the selection of the right covariates to remove the dependence between attacks when interpreting Series Hazard models.

The best fitted model (Table 2) included the 3-year impact of the commencement of the French deportation and extradition policy. French extradition policy has a positive coefficient: attacks increased in the three years following the French shift towards a harsher approach against alleged ETA militants living within their borders so a backlash effect may be assumed. The hazard of a new terrorist attack occurring increased between 8.4 and $48.8 \%$ compared to the rest of the study period.

\section{HERE TABLE 2}

In another model the French extraditions variable was incorporated as a one-year effect.Interestingly, this interventionleft the model and the GAL became a statistically significant backlash effect. As expected, there was amulticollinearityproblem between these two intervention variables: nowthe hazard ratio at the period of GAL operations was estimated between $0.7 \%$ and $36.7 \%$. As can be seen in Figure 1, the backlash effect comes from the two peaks of attacks in the time span covered by these interventions.

The multicollinearity observed between GAL and the French collaboration highlight one of the issues with the Series Hazard models: when two periods are largely overlapped, the model cannot differentiate the individual effects from each intervention. Since we cannot determine in which proportion the French extraditions were the reason for having an increase 
in the number of attacks compared to GAL, we assume both interventions were important and focus on determining whether the general effect is backlash or deterrence.

Whatever their differences -one is a programme of state terror, the other an initiative conducted under the rule of law- it is possible to perceive them as two facets of the same process: the growth in overt and covert repression exerted on ETA supporters in Southern France that undermined the reputation of the region as a terrorist sanctuary. We found in our analysis that part of the short-term backlash effect is explained in terms of the start of a campaign against French interests in Spain involving about 50 incidents, $16 \%$ of all the attacks carried out during the GAL intervention period.

Since both strategies remained in place by January 2011, we also measured the effects of French extradition policy and the illegalisation of Batasunauntil the end of the study to examine whether there would be substantial changes in the hazard ratios if we modified the interventions' end date. Since -unlike Batasuna- the French cooperation variable is statistically significant, we include the sensitivity analysis in Appendix C. The figure shows that the effects for the three-years and long-term periods are similar.

We tested all interactions between the interventions and the month of the attack since the beginning of the study. We found that the interaction with the 1978 Antiterrorist Law was statistically significant (p-value 0.009), which means that there is an important increase of the hazard ratio (i.e. backlash) during the time-window of the intervention (from 8.6\% to 97.2\% by the end of the interval). Figure 1 shows howthese years do include the largest upsurge in attacks found in the distribution and constitutes ETA's most active phase ever.

Surprisingly, there is not a statistically significant reduction of the hazard rate after Bidart,despite the graph in Appendix A showing a decrease in the number of incidents during the intervention period. Bidartis usually described in the literature as a severe blow to ETA that considerably eroded their capacity to act. Furthermore, the loss of the entire ETA leadership is often seen as being the catalyst for a radical change of strategy and the opening of a new stage in ETA's armed struggle. ${ }^{43}$ Appendix A seemed to support this view -a downward trend seems evident- but the model did not. We should highlight that these intervention periods included fairly low numbers of attacks and can lead to relatively large standard errors. This may mean that the model does not have enough statistical power to detect a small effect to compare to the underlying baseline. As Dugan states, for this model to work at its best, events must occur relatively frequently due to the fact that changes in temporal covariates are only measured during events. Since rare events can reduce statistical variation, the model is less likely to detect effects. ${ }^{44}$

Overall, a decreasing trend in number and frequency of terrorist incidents is observed. We find that the hazard of subsequent attacks increased following the passing of the 1978 Antiterrorist Law and the start of the French policy of deportations and extraditions and during the period of GAL activity. Three of the backlash effects are statistically significant (1978 Law, French extraditions and GAL). GAL and French extraditions presented a combined backlash effect. We turn now to the interpretation of these results. 


\section{Discussion}

The evolution of ETA violence is a multidimensional phenomenon reactivenot only to state policies but also to socio-political considerations in the Basque Country, internal debates within ETA itself and developments in other parts of Europe. Yet if we take a cursory look at the time series charts, they show a rather straightforward pattern: rapid growth of ETA violence in the mid-1970s, a dramatic escalation that reaches a peak in the 1978-1980 period and then a long, irreversible decline. To explain this evolution, generally the literature focuses on the following: the state meeting Basque aspirations for greater political autonomy within the framework of the Spanish constitution, the growing rejection and increasingly public opposition of most Basques to ETA violence, enhanced effectiveness and proportionality of the Spanish security services action, and gradually improving international cooperation. ${ }^{45}$ All these contribute to a general negative tendency -for ETA- that becomes more noticeable over the years and is reflected in the model by the role of cumulative month as a control variable. ${ }^{46}$ Hence, although Bidart, when considered independently, appears to result in a clear reduction in the prevalence of attacks, the effects seem simply to add to the overwhelming inertia leading to ETAs decline, rather than strongly changing the trend.

Regardless of the statistical significance of the impact from this widely-debated measure, the claims by critics that the banning of this political party would bring about new forms of grievances and more violence on the streets are clearly not evidenced in the data. It appears evident that the rejection of Batasuna members to this measure was more than counterbalanced by the dismantling of the sustained support that the party provided to the terrorist group. It also seems clear that these criticisms also failed to recognise the possibility that supporters of Basque independence would gravitate towards other political parties ${ }^{47}$ that were seeking the same political goal and, since they had no links with terrorist groups, were legal. This siphoning off support due to Batasuna's inability to join Basque's institutional politics strengthened those voices within the $M L N V$ that were critical of the instrumental use of violence and ETA's leadershipfaced heightened internal pressure to announce a ceasefire. $^{48}$

Regarding those variables still significant even after controlling for endogeneity, we find two interesting initiatives: the 1978 Antiterrorist Law and the 1984 French policy of deportations and extraditions. Both of them support backlash interpretations. This may come as a surprise to those who consider French-Spanish cooperation crucial to explain the extreme weakness of ETA's military apparatus today. We hasten to add that our results do not reject this claim, what they show is that, in the immediate short term, this measure led to a retaliatory response by ETA. This can be easily confirmed by examining the description of the incidents covered in the dataset, which show a growth in attacks against French commercial interests (i.e. automakers, supermarkets, banks and more) in Spain after 1984. As we established earlier, French-Spanish security cooperation is one of the main factors that are used by experts to explain the long-term general downward trajectory of ETA violence, yet the data seem to demonstrate that the immediate benefits gained were offset short-term by a spike of attacks in 
revenge of the French volte-face. We believe this to be an important finding as it warns against the temptation to consider an intervention as having the same outcome -either deterrence or retaliatory- over time: a particular strategy may not only eventually raise or lower its influence but, as in this case, have some initial costs but ultimately prove beneficial in reducing violence.

On the other hand, the introduction of the 1978 Law occurs throughout a rising wave of terrorist attacks by ETA, whose effect we controlled for in the model through the use of the attack density variable as control. In this respect, Clark argues that clearly the new Spanish counterinsurgency policy after 1 July,1978did little if anything to restrain ETA violence. ${ }^{49}$ At the same time, Jaime-Jiménez has also illustrated how the legislation was accompanied by the deployment of security forces to Basque Country that acted in occasions with excessive force and in a heavy-handed manner. ${ }^{50}$ Reinares has also highlighted in his interviews with former ETA militants the strong impact that personal and indirect experience with policy brutality during the 1970 s had in their decision to join the organisation. ${ }^{51}$ The Law is therefore illustrative of a broader policy shift by the government towards a more coercive approach that resulted in unconstitutional abuses of human rights.

At the same time, backlash may develop in subtler ways than simply as a short-term burst of attacks following an intervention. There may be deleterious long-term effects that are harder for the model to detect. For instance, there is much evidence that the GAL was not only a 'major departure from accepted liberal democratic constitutional principles of law and order ${ }^{52}$ but also profoundly counterproductive as it built the perception by a new generation of ETA recruits ofan oppressive Spanish state whose methods were no different from Franco. These events and the cases of police abuse and intimidation up until the mid-1980s helped to legitimise violence for many Basques and provided radicals with a rallying cry. It took years of selective and law-abiding counterterrorist practices to counterbalance these negative social perceptions. It is far from outlandish to think that the GAL may have contributed to extend ETA support for years.As Reinares and Jaime-Jiménez contend: 'state-sponsored terrorism used to counter insurgent terrorism can be considered a major factor explaining why ETA has persisted beyond the democratic transition. ${ }^{, 53}$

It should be noted that, despite the ample benefits that survival analysis models brings to our understanding of the effectiveness of specific counter-terror initiatives, there are alsolimitations in these approaches.Inevitably, they struggle to separate the effects of initiatives that are close in time, they work better at detecting immediate impact than identifying subtle,long-lasting outcomes and they do not recognise that the same intervention can elicit both short-term increases and long-term decreases of violence and viceversa. Furthermore, despite basing our selection of interventions on a careful and extensive review of the existing literature and previous research, it is conceivable that variables that are not in the model would have been potentially useful.These matters should be taken into consideration whenworking with these models rather than analysing the effects and simply assuming either deterrence or backlash.They also emphasise the relevance of contextual knowledge and subject matter expertise in ensuring an effective research design anda precise interpretation of the outputs from these statistical tests. 
With these disclaimers in mind, we are confident thatourfindings add further empirical evidence to the literature on backlash effects. One of our interventions (French extraditions) had clear short term negative effects and it is possible to argue that two others (Law 1978 and GAL) can be interpreted along those lines. At the same time, a measure (Batasuna's banning) that was forcefully predicted by some to lead to retaliation, failed to reignite political violence. All things considered, and in general agreement with LaFree et al's 2009 study of British counterterrorism in Northern Ireland, the evidence in our study suggests that some aggressive state responses in the past aggravated conflict levels in Basque Country.

This offers empirical support to the widely held notion that punitive counter-terror tactics can potentially have counterproductive effects. We have also speculated about the possibility that some initiatives could havenegative short-term consequences but bring long-term benefits while specially damaging actions involving egregious abuses of citizens' rights may result inboth immediate and enduringviolence. The Spanish case, as in Northern Ireland, also demonstrates how democratic governments can face much public pressure to adopt harsh repressive measures, even if these are also accompanied by constructive political strategies, when challenged by substantial levels of political violence within their borders. Yet it also provides support to the idea that democraciescan engage ina learning process when fighting terrorism, where heavy-handed action may become prevalent in an initial stage butprogressive refinement and adjustment can also occur, with the state acting in a more discriminateand legitimate manner, thus diminishing the risk of backfires.

The findings from our study are relevant to the subject of responses to criminal justice measures in a context of ethno-nationalist violence. As a natural extension of this research, a valuable approachmay be to adapt this perspective to the study of government responses to other types of violence, such as extreme left and right-wing movements or the actions of jihadist groups. Moreover, a greater body of evidence is required regarding the relationship between the probability of deterrence or escalation and the organisational characteristics of militant groups. Furthermore, and since explanations of backlash effects arepartially predicated on variations in recruitment patterns, it would be interesting to examinein more depth how changing patterns of violence, especially periods of increased terrorist activity, correlate with different indicators of public support for violent organisations (i.e. membership in certain political parties) over time. The possibilities are numerous and, regardless of the particular research question adopted, it is clear from the above that a judicious application of the concepts of deterrence and backlash can open new and fruitful avenues for the study of the effectiveness of counter-terrorism. 
Figures

Figure 1.Monthly time series of number of attacks, 1977-1993

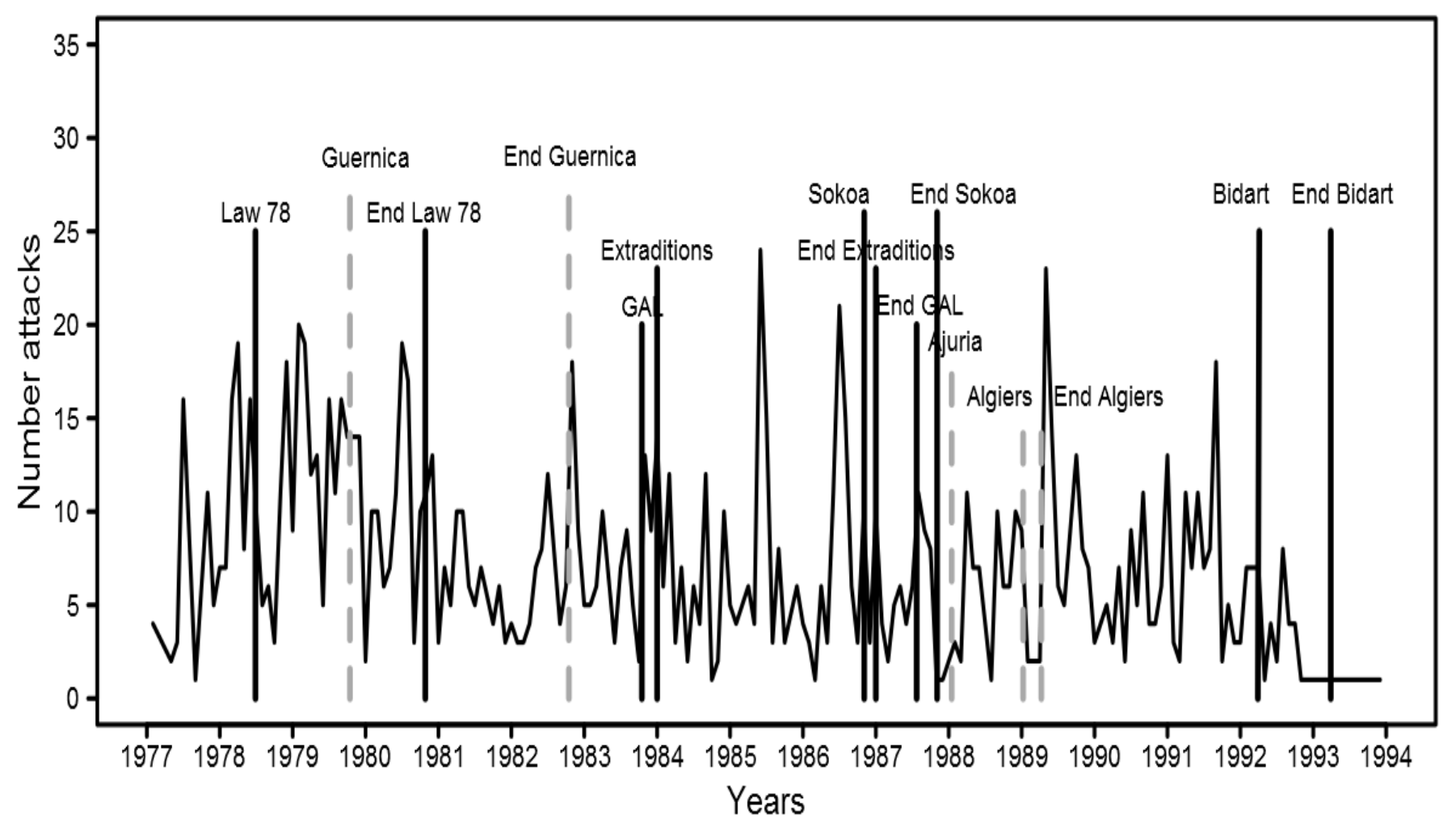


Figure 2. Monthly time series of number of attacks, 1994-2011

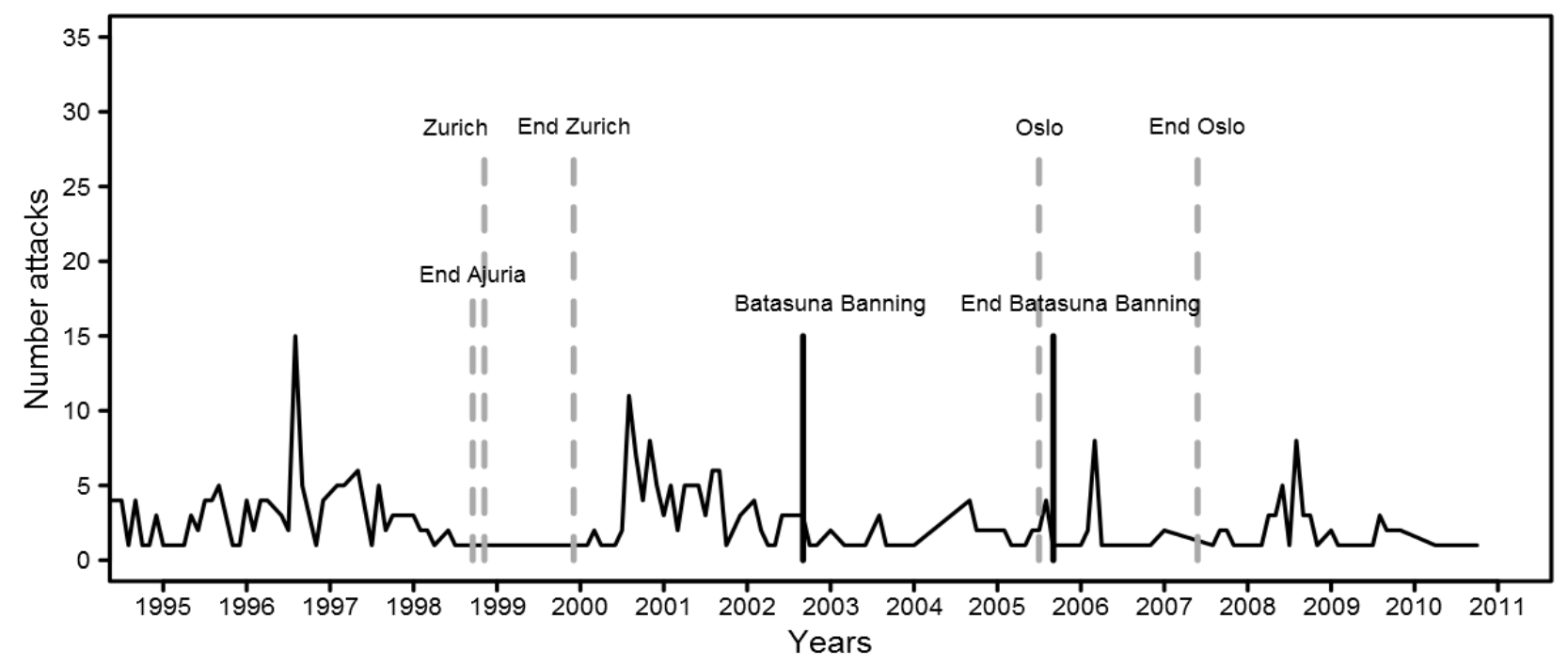


Appendix A. Yearly time series of number of attacks for the study period, 1977-2011

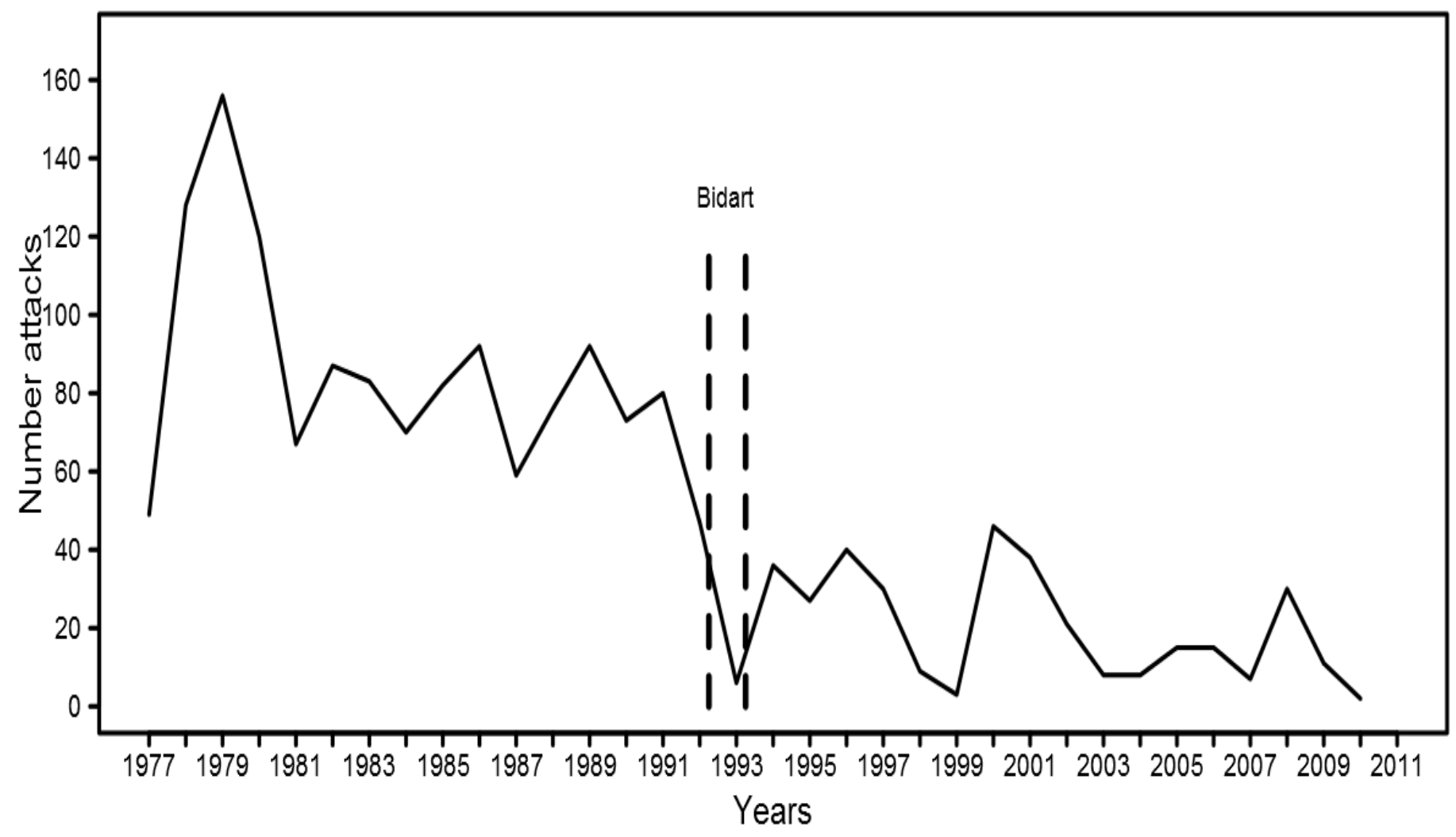


Appendix B. ETA Terrorist Attacks by province, 1977-2011

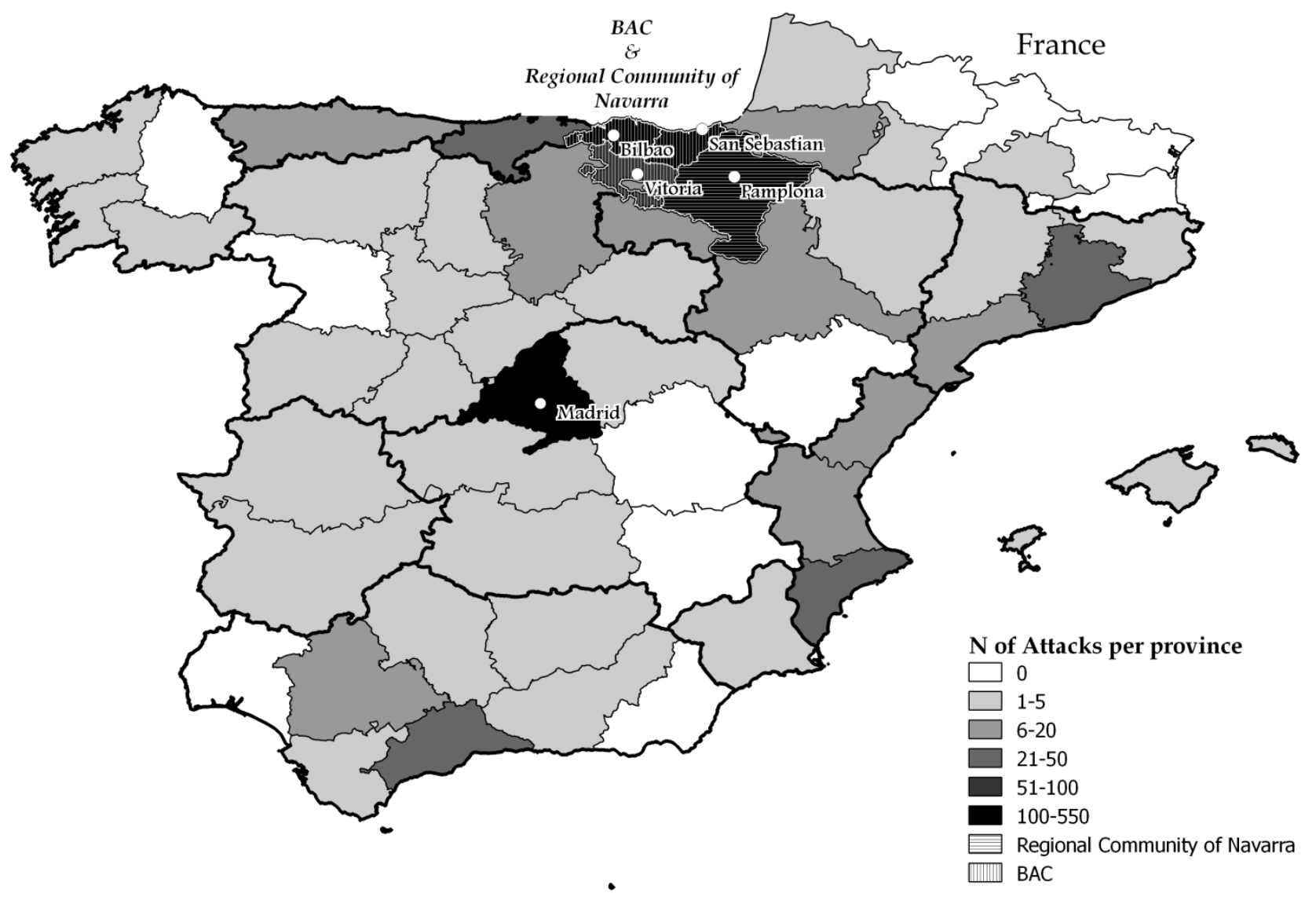




\section{Appendix C. Impact on hazard ratio of changing time-frame for French deportations and extraditions intervention ${ }^{1}$}

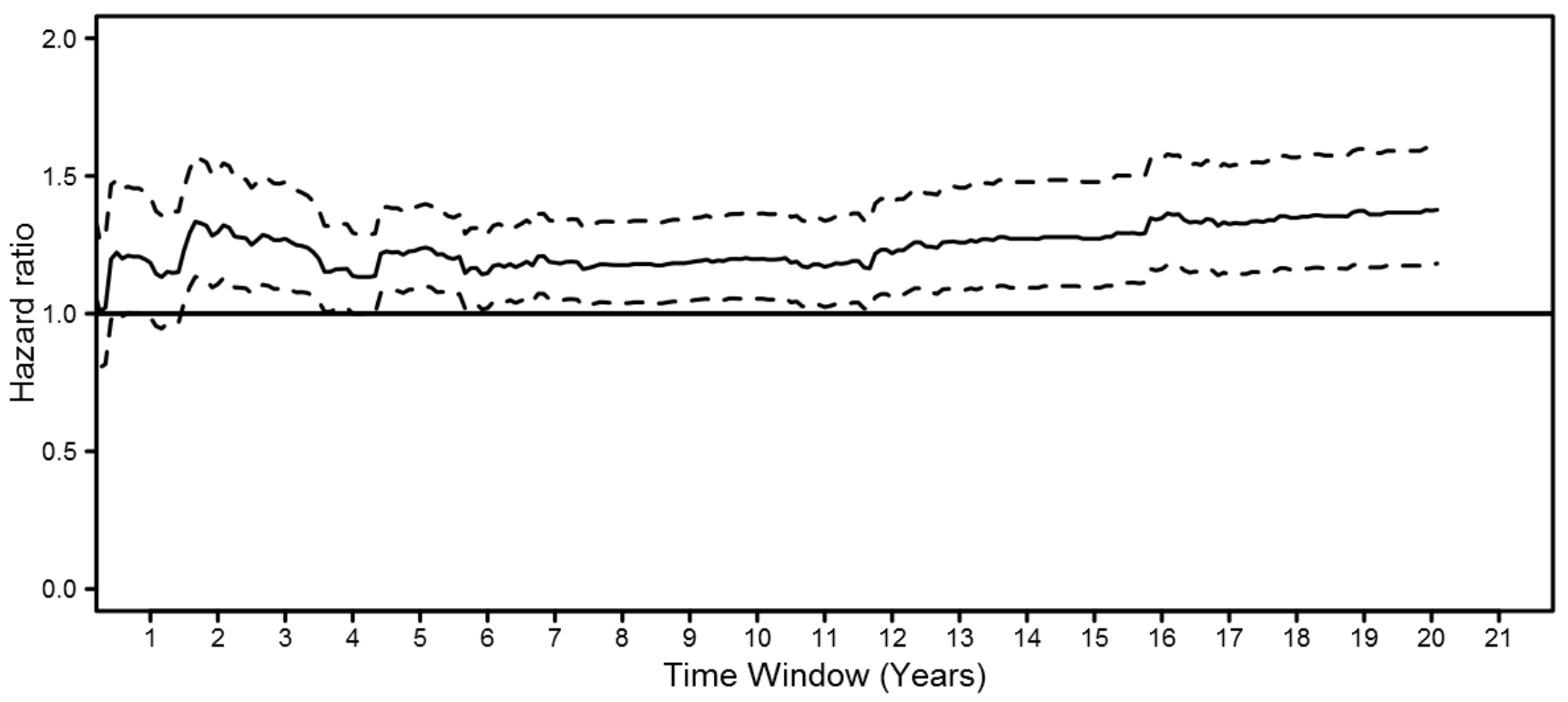

\footnotetext{
${ }^{1}$ Sensitivity analysis for the hazard ratio and confidence interval estimates from intervention "Deportations and extraditions by France" with a monthly time window increase. Itevaluates whether changes in the period of the intervention had an impact in its estimate of the hazard ratio. Models identical to the final model shown in Table 2 were fitted varying the duration of the intervention, from one month to 20 years increasing one month in each model. The scale of the graphs is in years for better visualisation.
} 


\section{Tables}

Table 1. Interventions and Controls included in the study with descriptive information

\begin{tabular}{|c|c|c|c|c|}
\hline Covariates & $\begin{array}{c}\text { Median (IQR) } \\
\text { Attacksfrequency }\end{array}$ & $\begin{array}{l}\text { \# attacks on } \\
\text { previous year }\end{array}$ & $\begin{array}{c}\# \text { attacks on } \\
\text { intervention/control }\end{array}$ & $\begin{array}{l}\text { \# attacks on } \\
\text { following year }\end{array}$ \\
\hline \multicolumn{5}{|c|}{$\begin{array}{l}\text { INTERVENTIONS } \\
\end{array}$} \\
\hline $\begin{array}{l}1978 \text { Anti- } \\
\text { terroristLaw } \\
(1 / 7 / 78-29 / 10 / 80)\end{array}$ & $1(4)$ & 100 & 310 & 78 \\
\hline $\begin{array}{l}G A L \\
(17 / 10 / 83-24 / 7 / 87)\end{array}$ & $2(6)$ & 76 & 310 & 58 \\
\hline $\begin{array}{l}\text { French deportations } \\
\text { and extraditions (1 yr) } \\
(1 / 1 / 84-1 / 1 / 85)\end{array}$ & $3(8)$ & 83 & 70 & 82 \\
\hline $\begin{array}{l}\text { French deportations } \\
\text { and extraditions (3yr) } \\
(1 / 1 / 84-1 / 1 / 87)\end{array}$ & $2(6)$ & 83 & 244 & 59 \\
\hline $\begin{array}{l}\text { Sokoa }(1 \text { yr) } \\
(5 / 11 / 86-5 / 11 / 87)\end{array}$ & $3(6)$ & 90 & 69 & 62 \\
\hline $\begin{array}{l}\text { Sokoa }(3 \mathrm{yr}) \\
(5 / 11 / 86-5 / 11 / 89)\end{array}$ & $3(4)$ & 90 & 229 & 65 \\
\hline $\begin{array}{l}\text { Bidart (1 yr) } \\
(29 / 3 / 92-29 / 3 / 93)\end{array}$ & $7(14)$ & 83 & 29 & 18 \\
\hline $\begin{array}{l}\text { Bidart(3 yr) } \\
(29 / 3 / 92-29 / 3 / 95)\end{array}$ & $8(21)$ & 83 & 73 & 34 \\
\hline $\begin{array}{l}\text { Batasuna banning } \\
\text { (1yr) } \\
\text { (26/8/02-26/8/03) }\end{array}$ & $18(43)$ & 25 & 11 & 5 \\
\hline $\begin{array}{l}\text { Batasuna banning } \\
\text { (3yr) } \\
(26 / 8 / 02-26 / 8 / 05)\end{array}$ & $16(38)$ & 25 & 34 & 14 \\
\hline \multicolumn{5}{|c|}{ CONTROLS } \\
\hline $\begin{array}{l}\text { Guernica statute }(1 \\
\text { yr) } \\
(15 / 10 / 79- \\
15 / 10 / 80)\end{array}$ & $2(3)$ & 167 & 115 & 82 \\
\hline $\begin{array}{l}\text { Guernica statute (3yr) } \\
(15 / 10 / 79- \\
15 / 10 / 82)\end{array}$ & $2(5)$ & 167 & 265 & 79 \\
\hline $\begin{array}{l}\text { Ajuria Enea Pact } \\
(12 / 1 / 88-12 / 9 / 98)\end{array}$ & $3(8)$ & 57 & 515 & 471 \\
\hline $\begin{array}{l}\text { Algiers } \\
(8 / 1 / 89-7 / 4 / 89)\end{array}$ & 0 & 77 & 0 & 104 \\
\hline $\begin{array}{l}\text { Zurich } \\
\text { (3/11/98 - 28/11/99) }\end{array}$ & $168(162)$ & 12 & 3 & 44 \\
\hline $\begin{array}{l}\text { Oslo } \\
\text { (25/6/05 - 21/5/07) }\end{array}$ & $7(25.5)$ & 14 & 24 & 16 \\
\hline
\end{tabular}


interventions

Density Date of current - date of the second previous event.

This variable represents the density of attacks.

Table 2.Parameter estimates for the main Series Hazard Model

\begin{tabular}{|c|c|c|c|}
\hline Variable & $\begin{array}{c}\text { Estimate } \\
\text { (Standard Error) }\end{array}$ & P-value & $\begin{array}{l}\text { Hazard Ratio } \\
\qquad(95 \% \mathrm{CL})\end{array}$ \\
\hline \multicolumn{4}{|c|}{ INTERVENTIONS } \\
\hline 1978 Anti-terroristLaw & $-0.3389(0.282)$ & 0.23 & \\
\hline GAL & $-0.133(0.154)$ & 0.39 & $0.875(0.646-1.186)$ \\
\hline $\begin{array}{l}\text { French deportations and } \\
\text { extraditions }\end{array}$ & $0.2392(0.081)$ & 0.003 & $1.27(1.084-1.488)$ \\
\hline Sokoa & $0.079(0.129)$ & 0.542 & $1.082(0.84-1.392)$ \\
\hline Bidart & $-0.124(0.192)$ & 0.518 & $0.883(0.606-1.287)$ \\
\hline Batasuna banning & $0.154(0.201)$ & 0.443 & $1.167(0.787-1.731)$ \\
\hline $\begin{array}{l}1978 \text { Anti-terrorist Law } \\
{ }^{*} \text { Cumulative month }\end{array}$ & $0.0222(0.0085)$ & 0.009 & $0.691^{2}(0.593-0.805)$ \\
\hline \multicolumn{4}{|c|}{ CONTROLS } \\
\hline Guernica statute & $-0.018(0.094)$ & 0.051 & $0.832(0.691-1.001)$ \\
\hline Ajuria Enea Pact & $0.0596(0.064)$ & 0.357 & $1.061(0.935-1.205)$ \\
\hline Algiers & $-0.07(0.515)$ & 0.893 & $0.933(0.34-2.559)$ \\
\hline Zurich & $1.186(0.829)$ & 0.153 & $3.275(0.645-16.64)$ \\
\hline Oslo & $0.206(0.239)$ & 0.389 & $1.23(0.77-1.96)$ \\
\hline Cumulative month & $-0.00076(0.00038)$ & 0.03 & \\
\hline Density & $-0.049(0.0023)$ & $<.0001$ & $0.95(0.948-0.957)$ \\
\hline
\end{tabular}

\footnotetext{
${ }^{2}$ Hazard ratio at the middle of the intervention period
} 


\section{Endnotes}

${ }^{1}$ Gary LaFree, Laura Dugan and Raven Korte, "The Impact of British Counterterrorist Strategies on Political Violence in Northern Ireland: Comparing Deterrence and Backlash Models," Criminology 47, no. 1 (2009): 501-530.

${ }^{2}$ Laura Dugan, Gary LaFree and Alex R. Piquero, "Testing a rational choice model of airline hijackings," Criminology 43, no. 4 (2005): 1031-66.

${ }^{3}$ Criminological research has foundnull effects, neither a clear deterrence nor backlash effect, when examining the impact of specific legislation on certain types of crimes: William AlexPridemore, W.A and Joshua D.

Freilich, "The impact of state laws protecting abortion clinics and reproductive rights on crimes against abortion providers: Deterrence, backlash, or neither?," Law and Human Behavior 31, no. 6 (2007): 611- 627.

${ }^{4}$ Audrey Kurth Cronin, How Terrorism Ends: Understanding the Decline and Demise of Terrorist Campaigns (Princeton: Princeton University Press, 2009); Martha Crenshaw, "How Terrorism Declines," Terrorism and Political Violence 3, no. 1 (1991): 69-87; Jeffrey Ross, "The Rise and Fall of Quebecois Separatist Terrorism; A Qualitative Application of Factors from two Models," Studies in Conflict and Terrorism 18, no. 4 (1995): 285-297; Jeffrey Ross and Ted Gurr, "Why Terrorism Subsides: A Comparative Study of Canada and the United States," Comparative Politics 21,no. 4 (1989): 405-426.

${ }^{5}$ LaFree et al (see note 1 above), 19.

${ }^{6}$ Interventions are understood here as criminal justice policies, initiatives and major individual security operations carried out in order to punish perpetrators of terrorist crimes and/or to raise the costs of engaging with terroristic activity.

${ }^{7}$ John A. Nevin, "Retaliating against terrorists,"Behavior and Social Issues 12, no. 2 (2003):109-28.

${ }^{8}$ Carlos P. Barros, “An Intervention Analysis of Terrorism: The Spanish ETA Case," Defence and Peace Economics 14, no. 6 (2003): 401-412.

${ }^{9}$ When data are aggregated in time-series analyses, especially at high levels such as annual data, statistical properties and interaction effects are lost and coefficients may be skewed and misinterpreted. See: Laura Dugan, "The Series Hazard Model: An Alternative to Time Series for Event Data", Journal of Quantitative Criminology 27 (2011): 379-402 and also Stephen M. Shellman, "Time Series Intervals and Statistical Inference: The Effects of Temporal Aggregation on Event Data Analysis," Political Analysis 12, No. 1 (2004): 97-104.

${ }^{10}$ Carlos Pestana Barros, José Passos and Luis A. Gil-Alana, "The timing of ETA terrorist attacks," Journal of Policy Modeling 28 (2006): 335-346, 344.

${ }^{11}$ This is reflected in the small size of the dataset, encompassing 111 observations over the 1968-2002 period. During those years ETA killed more than 800 people and conducted thousands of attacks.

${ }^{12}$ Evan Perkoski and Erica Chenoweth, The Effectiveness of Counterterrorism in Spain: A New Approach, Conference paper, Annual Meeting of the International Studies Association, New Orleans, February 20 th, 2010.

${ }^{13}$ Luis A. Gil-Alana and Carlos Pestana Barros, "A Note on the Effectiveness of National Anti-Terrorist Policies: Evidence from ETA", Conflict Management and Peace Science 27, no 1 (2010): 28-46.

${ }^{14}$ Both models share important security (France collaboration, GAL, Batasuna banning) and political initiatives (AjuriaEnea and Lizarra pacts,Lizarra is accounted here as coetaneous with the 'Zurich negotiation') but we add the latter as controls. In addition we introduce the high-profile Sokoa operation and the notoriously controversial 1978 Anti-terrorist Law as interventions and the Guernica Statute -the most important legislation of the period as it articulates the competencies of Basque governing bodies- and every important negotiation and ceasefire since one can safely assume they are associated with a reduction in violence- as controls.

${ }^{15}$ 'Basque Country' is understood here as the three provinces that constitute the Spanish administrative unit of the ComunidadAutónomaVasca (BAC - Basque Autonomous Community), that is, Álava, GuipúzcoaandVizcaya. ETA's political aspiration is to include in a separate state these three plus the separate Spanish autonomous community of Navarra (Navarre) and three other regions in Iparralde (Southern France): Lapurdi, NafarroaBeherea and Zuberoa.

${ }^{16}$ Alberto Abadie and Javier Gardeazabal, The economic costs of conflict: A case control study for the Basque Country, NEBR Working paper 8478 (Cambridge: NEBR, 2011).

${ }^{17}$ Not only by ETA but also other terrorist groups such as the extreme-left GRAPO and the extreme-right Batallón Vasco-Español (BVE). 
${ }^{18}$ Robert P. Clark, Negotiating with ETA. Obstacles to Peace in the Basque Country, 1975-1988 (Reno: University of Nevada Press, 1990), 41

${ }^{19}$ It was supplemented in this time span by two other pieces of legislation: 4 December 1978 Law 56/1978 and 26 January 1979 decree-law On the Protection of Citizen Security.

${ }^{20}$ Rogelio Alonso and Fernando Reinares, "Terrorism, Human Rights and Law Enforcement in Spain," Terrorism and Political Violence 17, no. 1-2 (2007): 265-278, 268.

${ }^{21}$ Paddy Woodworth, Clean Hands, Dirty War (Cork: University Press, 2001).

${ }^{22}$ Fernando Reinares and Oscar Jaime-Jiménez, "Countering Terrorism in a New Democracy: The Case of Spain," in Fernando Reinares (ed), European Democracies Against Terrorism. Governmental Policies and Intergovernmental Cooperation (Aldershot: Ashgate, 2000): 119-45.

${ }^{23}$ See: http://www.elmundo.es/eta/historia/golpe bidart.html

${ }^{24}$ Ignacio Sánchez-Cuenca, "The persistence of nationalist terrorism: the case of ETA," in KledjaMulaj (ed.), Violent non-state actors in contemporary world politics (New York: Columbia University Press, 2009), 69-92.

25 Florencio Domínguez, "ETA: Un Análisis de Situación," Cuadernos de pensamiento político, Octubre/Diciembre (2004), 93-116.

${ }^{26}$ Council of Europe Commissioner of Human Rights, Report by Alvaro Gil-Robles, Commissioner for Human Rights on his visit to Spain 10-19 March 2005 for the Attention of the Committee of Ministers and the Parliamentary Assembly. See:

https://wcd.coe.int/ViewDoc.jsp?id=927685\&Site=CommDH\&BackColorInternet=FEC65B\&BackColorIntrane $\mathrm{t}=$ FEC65B \&BackColorLogged $=$ FFC679

${ }^{27}$ National Consortium for the Study of Terrorism and Responses to Terrorism (START).(2012). Global Terrorism Database [Data file]. Retrieved from http://www.start.umd.edu/gtd

${ }^{28}$ For more information on the GTD see: Gary LaFree and Laura Dugan, "Introducing the global terrorism data base", Terrorism and Political Violence 19, no. 2 (2007): 181-204 and Gary LaFree, "The Global Terrorism Database: Accomplishments and Challenges", Perspectives on Terrorism 4, no. 1 (http://www.terrorismanalysts.com/pt/index.php/pot/article/view/89/html)

${ }^{29}$ More specifically, 97.6 percent of ETA attacks occurred within Spain. The remaining 2.4 percent were carried out abroad, overwhelmingly in Western Europe. This leaves 2 attacks to business interests in Mexico as the only incidents occurring outside the region.

${ }^{30}$ See for instance: http://www.interior.gob.es/prensa-3/balances-e-informes-21/ultimas-victimas-mortales-deeta-listado-631

${ }^{31}$ Rogelio Alonso, Florencio Domínguez y Marcos García Rey, Vidas rotas. Historia de los hombres, mujeres y niños víctimas de ETA (Madrid: Espasa, 2010).

${ }^{32}$ The GTD dataset is periodically updated and revised so data contents may vary depending on the accessed date. The data analysed here were downloaded in April 2013.

${ }^{33}$ Dugan (see note 9 above), 400.

${ }^{34}$ We include Medians and Interquartile range because of the positive skewness of the distribution.

${ }^{35}$ See: http://www.elmundo.es/especiales/2002/08/espana/batasuna/claves.html

${ }^{36}$ The kidnapping and assassination of alleged ETA members JoxeLasaArostegi and José Ignacio Zabala. Soon after, nationalists politicians blamed the crime on the security apparatus of the state.

${ }^{37}$ Assassination of Juan Carlos GarcíaGoena, who held no connection with ETA.

${ }^{38}$ The results of the simulation suggested that differences in AIC where only important forthe Guernica statute and French extraditionsvariables because Bidart, Sokoa and Batasuna banning were not significant. The AIC values for the 1 and 3 years time window scenarios for Guernica statute when French extraditions intervention is fixed to 1 year period were 8517.078 and 8512.008, respectively. When French extraditions intervention was assumed to last for 3 years, the AIC values for the 1 and 3 years scenarios of Guernica statute were 8509.968 and 8507.693, respectively.

${ }^{39}$ Clark, "Negotiating with ETA" (see note 18 above), 62.

${ }^{40}$ Robert P. Clark, The Basque Insurgents. ETA, 1952 -1980 (Madison: The University of Wisconsin Press, 1984), 252

${ }^{41}$ Dugan (see note 9 above)

${ }^{42}$ The three attacks model presented an AIC value 8556.946 compared to 8954.813, 9203.747 and 9163.617 obtained with the models using a density based on the seven previous attacks, an $\mathrm{AR}(1)$ and $\mathrm{AR}(3)$ term respectively.

${ }^{43}$ Ignacio Sánchez-Cuenca, "The persistence of nationalist terrorism: the case of ETA" (see note 24 above).

${ }^{44}$ Dugan (see note 11 above), 383.

45 Oscar Jaime-Jiménez, Policía, terrorismo y cambio político en España 1976-1996 (Valencia: Tirant lo Blanch, 2002), Alonso and Reinares (see note 20above) 


\footnotetext{
${ }^{46}$ The general trend can be said to broadly account for the general impact of other factors that are not in the model due to the absence of relevant information (i.e. annual number of police officers active in Basque Country).

${ }^{47}$ Essentially two: EuskoAlkartasuna and Aralar, which would later join the Bildu coalition of proindependence parties in 2010.

48 Florencio Domínguez, "La ruptura de la tregua y la situación del terrorismo de ETA," Cuadernos de pensamiento político, Abril/Junio (2007), 31-47.

${ }^{49}$ Clark, "The Basque Insurgents" (see note 40 above), 272.

${ }^{50}$ Jaime-Jiménez (see note 45 above).

${ }^{51}$ Fernando Reinares, Patriotas de la muerte: Por qué han militado en ETA y cuándo abandonan (Madrid: Taurus, 2011)

${ }^{52}$ Peter Chalk, "The response to terrorism as a threat to liberal democracy," Australian Journal of Politics and History 44, No 3 (1998): 373-88, 382.

${ }^{53}$ Reinares and Jaime-Jiménez (see note 22above), 136.
} 